\title{
ANALYSIS OF COURT PRACTICE OF DELIMITATION OF CAUSING SERIOUS INJURY WHICH HAS CAUSED DEATH AND PREMEDITATED MURDER
}

\section{АНАЛІЗ СУДОВОЇ ПРАКТИКИ РОЗМЕЖУВАННЯ СПРИЧИНЕННЯ ТЯЖКИХ ТІЛЕСНИХ УШКОДЖЕНЬ, ВНАСЛІДОК ЯКИХ НАСТАЛА СМЕРТЬ ТА УМИСНОГО ВБИВСТВА}

\section{Svetlana Shalgunova ${ }^{1}$} Alexandra Skok ${ }^{2}$

DOI: https://doi.org/10.30525/978-9934-588-53-2-41

Abstract. Today, one of the urgent problems of criminal justice is the investigation of the issues of delimitation of murder and intentional infliction of grievous bodily harm, which resulted in the death of the injured person, for which criminal responsibility for part 2 of Art. 121 of the Criminal Code of Ukraine. Despite the scientific research carried out in this area, there are some aspects that need more attention. The research used the dogmatic method, the method of system analysis, the statistical method, as well as the method of analysis and synthesis. In order to detail the criteria of differentiation, an analysis of statistical data was carried out over the last five years, which showed the positive dynamics of crimes under Part 2 of Art. 115 of the Criminal Code of Ukraine. In addition, the Resolution of the Plenum of the Supreme Court of Ukraine on the delineation of murder and grievous bodily harm that caused the victim's death was analyzed, and a theoretical analysis of the objective and subjective features of the crime was made. Particular attention was paid to the optional features of the objective side of the crime. Against this background, in order to differentiate intentional homicide from intentionally causing grievous

\footnotetext{
${ }^{1}$ Candidate of Juridical Sciences, Associate Professor,

Head of the Department of criminal-legal disciplines,

Dnipropetrovsk State University of Internal Affairs, Ukraine

${ }^{2}$ Candidate of Juridical Sciences,

Associate Professor at the Department of criminal-legal disciplines,

Dnipropetrovsk State University of Internal Affairs, Ukraine
} 
bodily harm that caused the death of a victim, it is necessary to carefully examine the evidence relevant to the purpose and purpose of the intent of the perpetrator. Based on the facts collected, it is possible to establish the subjective attitude of the perpetrator to the death of the victim as a result of grievous bodily harm. For the purpose of a more detailed examination of objective and subjective features, an analysis of the indictments of the courts of Ukraine under Part 2 of Art. 121 of the Criminal Code of Ukraine, which resulted in no less than 25 convictions additional circumstances were required to clarify for the purpose of final qualification and which, in turn, would be important in the delimitation of two related crime scenes. An analysis of the theoretical and practical components of the distinction of causing grievous bodily harm, which resulted in the death of the victim and premeditated murder, was made. Over the past five years, against the backdrop of a general reduction in the number of crimes against life and health, the crime rate in Part 2 of Art. 121 of the Criminal Code of Ukraine remains almost unchanged and ranges from a total number of $1.3-1.7 \%$, in contrast to the total number of serious injuries, namely from $27.1-31 \%$. In recent years, there has been a negative trend. An analysis of the caselaw on the delimitation of premeditated murder from grievous bodily harm indicates that the delimitation takes place on the subjective side, namely on the attitude of the perpetrator to the death of the victim.

\section{1. Вступ}

Злочини проти життя та здоров'я особи займають друге місце, за важливістю об'єкта кримінально-правової охорони, в системі кримінально караних діянь, передбачених чинним законом про кримінальну відповідальність. Визнання Конституцією України, в статті 3, людини, iї життя і здоров'я, честі і гідності, недоторканості і безпеки найвищою соціальною цінністю в Україні, - підкреслює значущість застосування інституту кримінальної відповідальності відносно осіб, винних у вчиненні кримінальних правопорушень, передбачених статтями 115 «Умисне вбивство» та статтею 121 «Умисне тяжке тілесне ушкодження» Кримінального кодексу України (далі - КК України).

3 початку існування Кримінального кодексу України, у вітчизняній кримінально-правовій науці, проблемні питання регламентації окремих злочинів проти життя та здоров'я особи породжували цікавість 
до розробок в науковому колі. Вагоме значення, в даному напрямку, мають дослідження, проведені на монографічному рівні Лускатовою Т.О. «Розслідування умисних тяжких тілесних ушкоджень, що спричинили смерть потерпілого» (Дніпропетровськ, 2015), Катеринчук К.В. «Кримінально-правова охорона здоров'я особи: доктринальні, законодавчі та правозастосовчі проблеми» (Ірпінь, 2019), Коломійцем В.Ю. «Кримінальна відповідальність за заподіяння тілесних ушкоджень» (Дніпро, 2019). Однак, наукові розробки щодо розмежування спричинення тяжких тілесних ушкоджень, внаслідок яких настала смерть потерпілого та умисного вбивства, - не втрачають своєї актуальності, що пов'язано із значною кількістю таких правопорушень та проблемами правозастосовної практики в частині їх правильної кваліфікації.

\section{2. Аналіз стану злочинності проти життя та здоров'я особи}

За офіційними даними Генеральної прокуратури України за 2015 рік всього обліковано злочинів проти життя та здоров'я - 53 794, з них за ст. 115 КК України - 8 224; ст.ст. 116-120 КК України - 311; ст. 121 КК України - 2 511; ч. 2 ст. 121 КК України (за кваліфікуючою ознакою, тяжкі тілесні ушкодження, які спричинили смерть потерпілої особи) 680, що склало 1,3\% від загальної кількості злочинів проти життя та здоров'я; питома вага від загальної кількості вчинених злочинів за ст. 121 КК України - 27,1\%, від загальної кількості вбивств - 8,3\% [1].

За 2016 рік: всього зареєстровано злочинів проти життя та здоров'я 45 979, $з$ них за ст. 115 КК України - 5992 злочини; ст.ст. 116-120 КК України - 382; ст. 121 КК України - 2 256; ч. 2 ст. 121 КК України (за кваліфікуючою ознакою, тяжкі тілесні ушкодження, які спричинили смерть потерпілої особи) - 698 злочинів, що становить 1,5\% від загальної кількості злочинів проти життя та здоров'я, питома вага від загальної кількості вчинених злочинів за ст. 121 КК України - 30,9\%, від загальної кількості вбивств - 11,6\% [2].

За 2017 рік: всього зареєстровано злочинів проти життя та здоров'я 38 274, з яких за ст. 115 КК України - 5145 злочинів; ст.ст. 116-120 КК України - 278 злочинів; ст. 121 КК України - 2 096; ч. 2 ст. 121 КК України (за кваліфікуючою ознакою, тяжкі тілесні ушкодження, які спричинили смерть потерпілої особи) - 613 злочинів, що становить 1,6\% від загальної кількості злочинів проти життя та здоров'я, питома 
вага від загальної кількості вчинених злочинів за ст. 121 КК України 29,2\%, від загальної кількості вбивств - 11,9\% [3].

За 2018 рік: всього зареєстровано злочинів проти життя та здоров'я 39 164, з них за ст. 115 КК України - 5 557; ст.ст. 116-120 КК України 294; ст. 121 КК України - 2 130; ч. 2 ст. 121 КК України (за кваліфікуючою ознакою, тяжкі тілесні ушкодження, які спричинили смерть потерпілої особи) - 661 злочинів, що склало 1,7\% питомої ваги від загальної кількості злочинів проти життя та здоров'я, питома вага від загальної кількості вчинених злочинів за ст. 121 КК України - 31\%, від загальної кількості вбивств - 11,9\% [4].

За 2019 рік: всього зареєстровано злочинів проти життя та здоров'я 41101 злочинів, з них за ст. 115 КК України - 5465 злочинів; ст.ст. 116-120 КК України - 270 злочинів; за ст. 121 КК України - 1 940; ч. 2 ст. 121 КК України (за кваліфікуючою ознакою, тяжкі тілесні ушкодження, які спричинили смерть потерпілої особи) - 579 злочинів, що склало 1,4\% від загальної кількості злочинів проти життя та здоров'я, питома вага від загальної кількості вчинених злочинів за ст. 121 КК України - 29,9\%, від загальної кількості вбивств - 10,6\% [5].

Так, ми можемо побачити, що за останні п’ять років на фоні загального зниження кількості злочинів проти життя та здоров'я особи рівень злочинів за ч. 2 ст. 121 КК України залишається майже незмінним та коливається від загальної кількості таких злочинів в межах 1,3\% 1,7\%. Натомість, від загальної кількості спричинених тяжких тілесних ушкоджень коливається в межах 27,1\% - 31\%.

\section{3. Тяжкі тілесні ушкодження, що спричинили смерть потерпілої особи}

Частина 2 ст. 121 КК України містить наступні кваліфікуючи ознаки: спосіб, що має характер особливого мучення; вчинене групою осіб; 3 мотивів расової, національної або релігійної нетерпимості; вчинене на замовлення; що спричинило смерть потерпілої особи.

Тяжке тілесне ушкодження кваліфікується за ч. 2 ст. 121 КК України, якщо внаслідок нього була спричинена смерть потерпілого.

Згідно п. 2 Постанови Пленуму Верховного Суду України (далі ППВСУ) № 2 від 07.02.2003 року, при призначенні покарання відповідно до статей 65-69 КК України суди мають ураховувати ступінь 


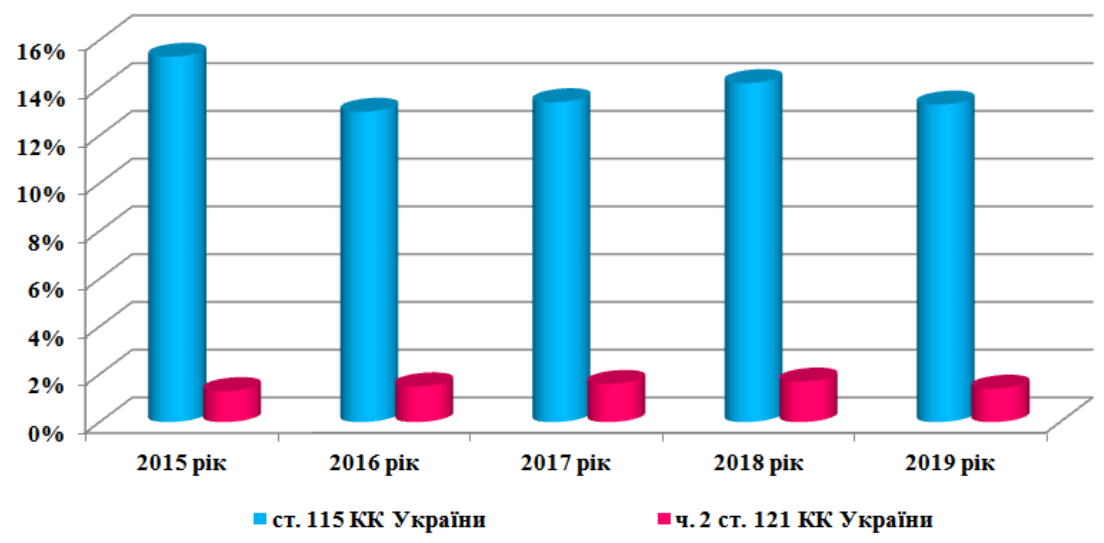

Діаграма 1. Відсоткове співвідношення злочинів, передбачених ст. 115 та ч. 2 ст. 121 КК України від загальної кількості злочинів проти життя та здоров'я особи за 2015-2019 роки

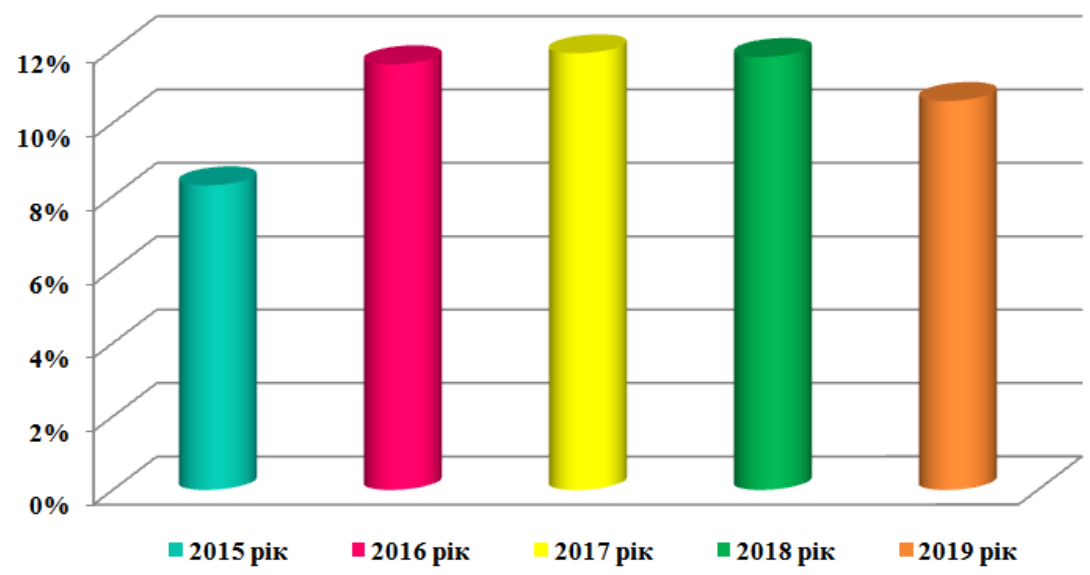

Діаграма 2. Відсоток тяжких тілесних ушкоджень, які спричинили смерть потерпілої особи від умисних вбивств за 2015-2019 роки 
тяжкості вчиненого злочину, сукупність усіх обставин, що його характеризують (форма вини, мотив, спосіб, характер вчиненого діяння, ступінь здійснення злочинного наміру, тяжкість наслідків тощо), особу винного й обставини, що пом'якшують та обтяжують покарання. Положення п. 22 ППВСУ № 2 від 07.02.2003 року визначають, що для відмежування умисного вбивства від умисного заподіяння тяжкого тілесного ушкодження, яке спричинило смерть потерпілого (ч. 2 ст. 121 КК України), необхідно ретельно досліджувати докази, що мають значення для з'ясування змісту і спрямованості умислу винного. Питання про умисел необхідно вирішувати виходячи із сукупності всіх обставин вчиненого діяння, зокрема враховувати спосіб, знаряддя злочину, кількість, характер і локалізацію поранень та інших тілесних ушкоджень, причини припинення злочинних дій, поведінку винного i потерпілого, що передувала події, їх стосунки. Визначальним при цьому є суб' єктивне ставлення винного до наслідків своїх дій: при умисному вбивстві настання смерті охоплюється умислом винного, а в разі заподіяння тяжкого тілесного ушкодження, яке спричинило смерть, ставлення винного до ії настання характеризується необережністю [6].

Зокрема, для відмежування умисного вбивства (ст. 115 КК України) від умисного спричинення тяжкого тілесного ушкодження, яке спричинило смерть потерпілого (ч. 2 ст. 121 КК України) обов'язкові ознаки об'єктивної сторони необхідні для з'ясування: обставин вчиненого діяння; способу спричинених тілесних ушкоджень; знаряддя; кількості завданих ударів; характеру та локалізації спричинених тілесних ушкоджень. 3'ясування вказаних обставин дає змогу відмежування умисного вбивства (ст. 115 КК України) та умисного спричинення тяжкого тілесного ушкодження, що спричинило смерть потерпілого (ч. 2 ст. 121 КК України).

Однак, незважаючи на роз'яснення Верховного Суду щодо розмежування умисного вбивства та тяжких тілесних ушкоджень, що спричинили смерть потерпілого, можна спостерігати труднощі щодо кваліфікації цих діянь на практиці.

Так, наприклад Кіровським районним судом м. Кіровограда було встановлено, що 14.02.2019 року близько 18 години 00 хвилин у особи виник умисел на спричинення тілесних ушкоджень своїй цивільній дружині на грунті ревнощів. Реалізовуючи свій умисел, винний, не передбачаючи можливість настання суспільно небезпечних наслідків свого 
діяння у вигляді смерті потерпілої, хоча повинен був їх передбачити, взяв ніж та тримаючи його у руці, наніс один удар в область лівого плеча потерпілій, однак ніж пройшов наскрізь через плече потерпілої та, поранив ліву молочну залозу останньої. Смерть потерпілої настала від проникаючого в грудну порожнину поранення з пошкодженням серця. Таким чином, винний вчинив вбивство через необережність, тобто кримінальне правопорушення, передбачене ч. 1 ст. 119 КК. Однак, попередня кваліфікація діяння була за ч. 2 ст. 121 КК України [7].

Колегія суддів Першої судової палати Касаційного кримінального суду у складі Верховного Суду дала пояснення щодо такого розмежування, зокрема питання про умисел необхідно вирішувати виходячи із сукупності всіх обставин вчиненого діяння, зокрема враховувати спосіб, знаряддя злочину, кількість, характер і локалізацію поранень та інших тілесних ушкоджень, причини припинення злочинних дій, поведінку винного і потерпілого, що передувала події, їх стосунки [8].

Отже, до перелічених вище обставин, необхідних для з'ясування варто додати ще наступні: причини припинення злочинних діянь, поведінку винного і потерпілого, щзо передувала події, їх стосунки. На нашу думку, з'ясування в повному обсязі необхідних даних об'єктивної сторони надасть змогу встановити дійсні наміри винної особи.

Перелік таких обставин не може бути вичерпним чи обов'язковим для з'ясування. Однак, якщо для правильної кваліфікації недостатньо обставин, необхідно встановити й інші, які б вказали на ставлення винного до настання смерті потерпілого, то необхідно врахувати й інші обставини, зокрема пов'язати ступінь алкогольного сп'яніння винної особи та потерпілого, поведінку винного після припинення злочинних дій та стан потерпілого в цей час. Також, важливе значення для з'ясування матиме тривалість нанесення тілесних ушкоджень.

Обставиною вчиненого діяння визнається явище, подія, або факти, що пов'язані із злочином.

Спосіб вчинення злочину - це застосування або використання винною особою певних прийомів, методів, послідовних рухів під час вчинення злочину.

Знаряддя злочину - це предмет за допомогою чого скоєно злочин. Слід зазначити, що характеристика властивості таких предметів буде мати важливе значення. 
Характер та локалізащія, спричинених тілесних ушкоджень, кількість завданих ударів - обов'язково повинно бути враховано при кваліфікації діяння.

Причини припинення злочинної діяльності - те, що спонукало припиненню нанесення тілесних ушкоджень. Наприклад, досягнення мети, тобто спричинення тілесних ушкоджень, жалість до потерпілого, побоювання нести кримінальну відповідальність, смерть потерпілого та інші причини.

Поведінка винного та потерпілого, щуо передувала - в більшості випадків злочинній поведінці передували неприязні стосунки з потерпілими.

Попередні стосунки винного та потерпілого - попередніми стосунками можна вважати: родинні зв'язки (подружні, батьки - діти, дід, баба - онуки та інше), товариські стосунки, сусідство, тривалість знайомства, спільне розпиття спиртних напоїв, колеги по роботі та інше. Що стосується родинних зв'язків, то можемо зазначити, що їх наявність суд визнає як обтяжуючу обставину, передбачену п. $6^{1}$ ст. 67 КК України. Так, із 25 проаналізованих обвинувальних вироків судів України, у 10 випадках винна особа та потерпілий перебували у родинних відносинах.

Стан потерпілого після спричинення тілесних ушкоджень до настання смерті - також може дати уявлення про наміри та мету винного. Наприклад: можливість ходити, говорити, відмова від надання медичної допомоги чи навпаки, безпорадний стан. I на цьому етапі важливо з'ясувати поведінку винної особи щодо стану потерпілого та припинення своїх злочинних дій.

Так, наприклад, Олександрійський міськрайонний суд Кіровоградської області встановив, що винний, знаходячись за місцем свого проживання, в ході сварки спричинив не менше 27 ударів руками та ногами по різним частинам тіла своїй співмешканці. За висновком судово-медичного експерта на підставі даних експертизи трупа потерпілої, беручи до уваги обставини справи, дійшов наступного висновку: після отримання тілесних ушкоджень потерпіла могла самостійно пересуватися, вчиняти цілеспрямовані активні дії, (підійматись, рухатись, ходити, говорити та інше). Судово-медичні дані, протягом якого часу це було можливим, - відсутні. Комплекс виявлених на тілі потерпілої тілесних ушкоджень утворився внаслідок мінімум 27 травматичних 
впливів. Ознак захворювань які б могли спричинити смерть потерпілої, при дослідженні її тіла, не виявлено [9].

Враховуючи висновок судово-медичного експерта та поведінку в цей час винного у сукупності з іншими об'єктивними ознаками можна дійти висновку про ставлення винного до настання смерті потерпілої, яке вказує про добровільне припинення своєї подальшої злочинної діяльності для спричинення смерті. Побиття було припинено, тож можна говорити про наявний умисел щодо спричинення тяжких тілесних ушкоджень, а не смерті потерпілої, яка настала через деякий час.

Окрім того, Комінтернівським районним судом м. Харкова було встановлено, що винний, перебуваючи у стані алкогольного сп'яніння, під час спільного вживання напоїв зі своїм знайомим, який $\epsilon$ особою похилого віку, з мотивів раптово виниклих особистих неприязних відносин між ними, маючи мету направлену на спричинення потерпілому тілесних ушкоджень, діючи умисно, усвідомлюючи протиправність та суспільно-небезпечний характер своїх дій, стоячи напроти потерпілого, обличчям один до одного на відстані витягнутої руки, наніс один удар кулаком правої руки, в область очей потерпілому, спричинивши останньому садно на лівому крилі носа зліва та синець біля внутрішнього кута лівого ока, які є легкими тілесними ушкодженнями. Від даного удару потерпілий, втратив рівновагу та впав на підлогу, від чого у нього утворився синець на задній поверхні грудної клітини (спині) зліва, який є легкими тілесними ушкодженнями. Після чого, винний, продовжуючи реалізацію свого умислу, направленого на спричинення тілесних ушкоджень потерпілому, сів на останнього, який лежав на спині обличчям догори та став наносити чисельні удари кулаками обох рук в область голови, грудної клітини та шиї потерпілого, від чого у останнього утворились такі тілесні ушкодження, від яких потерпілий помер на місці. Причиною смерті потерпілого стала закрита тупа травма шиї, з розвитком гострого розладу кровообігу. По ступеню тяжкості, вказана травма шиї носить ознаки тяжких тілесних ушкоджень. Інші ушкодження: травма тулуба 3 переломами ребер, відносяться до тілесних ушкоджень середньої тяжкості по критерію тривалості розладу здоров'я. Тілесні ушкодження на голові (забійні рани, садна, синці) відносяться до легких тілесних ушкоджень [10]. 
Так, ми можемо побачити не повний але чисельний перелік обставин, які можуть мати значення для правильної кваліфікації та відмежування досліджуваних складів злочинів.

Якщо винний діяв з умислом на вбивство, тривалість часу, що минув 3 моменту заподіяння ушкоджень до настання смерті потерпілого, для кваліфікації злочину як умисного вбивства значення не має.

Так, судом Самбірського міськрайонного суду Львівської області від 01.04.2020 року встановлено, що на грунті раптово виниклих неприязних відносин, маючи умисел на спричинення тілесних ушкоджень, винний умисно наніс потерпілому декілька ударів кулаком, ногами та дерев'яною палицею в голову, тулуб та кінцівки, спричинивши тілесні ушкодження у вигляді перелому кісток носа, поперекового перелому тіла грудини в 3-4 міжребер'ї, крововилив в ділянці перелому, переломи 5-8 ребер справа, переломи 3-7 ребер зліва, крововилив у товстий відділ попереково-ободового відділу кишківника, які відносяться до середнього ступеня тяжкості тілесного ушкодження, а внаслідок ускладнення, пов'язаного із гострою зовнішньою і внутрішньою кровотечею та геморагічно-травматичним шоком у своїй сукупності відносяться до тяжких тілесних ушкоджень, від яких потерпілий помер на місці події, тобто винний заподіяв умисне тяжке тілесне ушкодження, щуо спричинило смерть потерпілого, а саме, вчинив злочин, передбачений ч. 2 ст. 121 КК України. Перелічені ушкодження ускладнилися виникненням гострої зовнішньої і внутрішньої крововтрати та травматичного шоку і в своїй сукупності відносяться до тяжкого тілесного ушкодження, що являється небезпечним для життя в момент його заподіяння і перебуває в причинно-наслідковому зв'язку із настанням смерті потерпілого [11].

Так, з обвинувального вироку ми можемо побачити, що судом 3'ясовані наступні обставини: знаряддя вчинення злочину - дерев'яна палиця (конкретно не зазначений розмір, вага та інші характеристики, що б мали значення для встановлення намірів винної особи), а також удари наносились руками та ногами; кількість нанесених ударів - по декілька у різні частини тіла; локалізація нанесених ударів - голова, тулуб, кінцівки; характер спричинених тілесних ушкоджень - політравми: перелам кісток носу, перелами ребер, перелам тіла грудини, що викликало гостру зовнішню та внутрішню кровотечу, що спричинило 
смерть потерпілого одразу після спричинення тілесних ушкоджень. Отже, за об'єктивними ознаками: діяння у вигляді активної дії, - побиття; суспільно-небезпечні наслідки - тяжкі тілесні ушкодження за ознакою небезпеки для життя, що призвело до смерті потерпілого та причинно-наслідковий зв'язок між побиттям та настанням смерті, збігається з умисним вбивством. Однак, локалізація тілесних ушкоджень може вказувати на намір спричинення тілесних ушкоджень, а саме нанесення ударів по обличчю (перелам кісток носу), нанесення ударів по кінцівках. Характер спричинених тілесних ушкоджень, за висновком судово-медичної експертизи від 12 липня 2019 року відомо, що безпосередньою причиною смерті потерпілого є політравма у вигляді переламу кісток носа, множинними переламами ребер, як справа так і зліва, поперековим переламом тіла груднини, множинними крововиливами та синцями 3 локалізацією на тулубі та нижніх кінцівках, що ускладнилося гострою крововтратою (накопиченням крові довкола синців, крововиливів та переламів кісток скелету), що ускладнилося виникненням геморагічно-травматичного шоку. Все це підтверджується такими ознаками, як-от: скудні трупні плями, кахектична тілобудова, набряк головного мозку, виражені ознаки носової кровотечі із затіканням крові у великі дихальні шляхи, перелами тіла груднини, наявність множинних синців та крововиливів в ділянці тулуба, нижніх кінцівок, а також результати судово-гістологічного дослідження внутрішніх органів. Такі ушкодження, як синець в ділянці тіла груднини, перелам тіла грудини; множинні перелами ребер як справа так і зліва від груднини, крововилив у брижу товстого кишківника, перелам кісток носа, множинні смугоподібні крововоливи на грудях справа та на лівому стегні, а також крововиливи на обох нижніх кінцівках, - утворилися від дії твердого предмету, можливо палиці, кулаків та обутих в черевики ніг. Множинні перелами ребер, перелам тіла груднини відноситься до ушкодження середнього ступеня тяжкості за ознакою довготривалого розладу здоров'я; крововиливи в ділянці тіла, нижніх кінцівок, садна та рани в ділянці обличчя та передньої поверхні тулуба відносяться до легкого тілесного ушкодження. Перелічені ушкодження ускладнилися виникненням гострої зовнішньої і внутрішньої крововтрати та травматичного шоку і в своїй сукупності відносяться до тяжкого тілесного ушкодження, щзо є небезпечним для життя в 
момент його заподіяння і перебуває в причинно-наслідковому зв'язку із настанням смерті потерпілого [11].

Слід звернути увагу на те, що саме об'єктивні ознаки дали змогу суду встановити наміри винної особи, що дало підстави кваліфікувати дії винного не за ст. 115 КК України, а за ч. 2 ст. 121 КК України.

\section{4. Визначення ознак суб'єктивної сторони ч. 2 ст. 121 КК України}

Суб'єктивна сторона ч. 2 ст. 121 КК України характеризується складною (подвійною, змішаною) формою вини, тобто наявністю в одному складі злочину двох різних форм вини: умислу і необережності, які існують незалежно одна від одної і не перетинаються.

Мотив та мета умисного спричинення тяжкого тілесного ушкодження, внаслідок якого настала смерть, на кваліфікацію не впливають, однак обов'язково повинні бути враховані при призначенні покарання.

Так, умисна форма вини, у вигляді прямого умислу, притаманна спричиненню тяжких тілесних ушкоджень, відносно настання суспільно-небезпечних наслідків у вигляді смерті потерпілого, - вина у формі необережності. За наявності необережності щодо діяння і наслідків кваліфікація за ч. 2 ст. 121 КК України - відсутня. В цьому випадку можлива кваліфікація за ст. 119 КК України. Якщо ж ставлення до настання наслідків у вигляді смерті у формі прямого умислу, тоді діяння підлягає кваліфікації за ст. 115 КК України.

Щодо психічного ставлення винної особи до різних наслідків, передбачених ч. 2 ст. 121 КК України, то психічне ставлення до настання наслідків у вигляді спричинення тяжких тілесних ушкоджень з прямим умислом, а от щодо смерті особи, з необережністю.

Відповідно до п. 26 ППВСУ № 2 «...у випадках, коли особа, яка позбавила потерпілого життя чи заподіяла йому тяжке тілесне ушкодження, передбачала можливість настання шкідливих наслідків своїх дій чи бездіяльності, але легковажно розраховувала на їх відвернення (злочинна самовпевненість), або ж не передбачала можливості настання таких наслідків, хоча повинна була й могла їх передбачити (злочинна недбалість), іiї дії слід розглядати як убивство через необережність чи заподіяння необережного тяжкого або середньої тяжкості тілесною ушкодження і кваліфікувати відповідно за ст. 119 КК України чи ст. 128 КК України...» [6]. 
Для відмежування умисного вбивства від умисного заподіяння тяжкого тілесного ушкодження, яке спричинило смерть потерпілого, необхідно ретельно досліджувати докази, що мають значення для з'ясування змісту і спрямованості умислу винного. Питання про умисел необхідно вирішувати виходячи із сукупності всіх обставин вчиненого діяння, зокрема враховувати спосіб, знаряддя злочину, кількість, характер і локалізацію поранень та інших тілесних ушкоджень, причини припинення злочинних дій, поведінку винного і потерпілого, що передувала події, їх стосунки. Визначальним при цьому є суб'єктивне ставлення винного до наслідків своїх дій: при умисному вбивстві настання смерті охоплюється умислом винного, а в разі заподіяння тяжкого тілесного ушкодження, яке спричинило смерть потерпілого, ставлення винного до її настання характеризується необережністю [8].

Так, Шепетівським міськрайонним судом Хмельницької області було встановлено, що 3 вересня 2019 року близько 02 год. 20 хв. винна, 3 метою встановлення місця перебування свого співмешканця, припускаючи, що він перебуває у іншої жінки, прийшла до ії квартири та, зайшовши з їі дозволу, виявила на балконі співмешканця, який переховувався від неї, та нанесла йому один удар долонею правої руки в обличчя. Винна, будучи обуреною обманом та зневажливою поведінкою до неї, під час словесного конфлікту, на грунті ревнощів, умисно нанесла власниці квартири два удари долонями рук в обличчя. В подальшому, обома руками схопила іiі за волосся та, шарпаючи, перемістила потерпілу в коридор квартири. Не зважаючи на дії співмешканця, який намагався припинити конфлікт, винна умисно нанесла один удар кулаком руки в ділянку носа жінці, від якого потерпіла втратила рівновагу та через відкриті вхідні двері в квартиру, впала спиною на бетонну поверхню сходової площадки, вдарившись потиличною ділянкою голови. Згодом, винна умисно, схопивши за одяг потерпілу, підтягнула та кинула, внаслідок чого остання знову впала та вдарилася потиличною ділянкою голови об сходову площадку. В подальшому, прикладаючи значну фізичну силу та, утримуючи потерпілу за одяг, котра перебувала у безпорадному стані, винна умисно протягнула іiі бетонними сходами вниз до сходової площадки між другим та першим поверхами, внаслідок чого потерпіла, неодноразово, вдарялася до виступаючих частин бетонних сходів головою та іншими частинами тіла. В резуль- 
таті таких дій, потерпілій було завдано тілесні ушкодженні у вигляді відкритої черепно-мозкової травми в сукупності з іншими травмами, що відносяться до тяжких тілесних ушкоджень, як небезпечні для життя в момент заподіяння, що призвели до смерті потерпілої особи. Відповідно до висновку комплексної судової психолого-психіатричної експертизи обвинувачена на момент вчинення інкримінованого їй злочину не перебувала в стані афекту, стресу та фрустрації, які є підставою для кваліфікації «сильного душевного хвилювання» (юридична категорія) [12].

Не можна, зокрема, розглядати як умисне вбивство випадки, коли смерть потерпілого настала від ушкодження, одержаного при падінні від поштовху чи удару, якщо винний не бажав або свідомо не припускав настання таких наслідків. Такі дії, залежно від змісту суб'єктивної сторони злочину, можуть кваліфікуватися як вбивство через необережність чи як умисне тяжке тілесне ушкодження, що спричинило смерть потерпілого.

Вбивство чи заподіяння тілесних ушкоджень, внаслідок злочинної самовпевненості необхідно відмежовувати від вчинення цих діянь із непрямим умислом (коли винна особа передбачала і свідомо припускала настання відповідних наслідків, не розраховуючи при цьому на конкретні обставини, які могли б його відвернути), а вбивство чи заподіяння тілесних ушкоджень внаслідок злочинної недбалості - від невинного заподіяння шкоди (коли особа не передбачала настання відповідних наслідків, не повинна була і (або) не могла їх передбачати).

Відповідно до ч. 2 ст. 242 Кримінального процесуального кодексу України для встановлення причин смерті, тяжкості й характеру тілесних ушкоджень, - слідчий або прокурор зобов'язані забезпечити проведення експертизи.

Відповідно до п. 27 ППВСУ № 2, «...при цьому слід враховувати, що визначення наявності ознак особливої жорстокості, мучення, мордування, катування, знівечення обличчя є компетенцією суду. Встановлювати ж, чи є знівечення обличчя непоправним, необхідно за допомогою судово-медичної експертизи. Водночас треба мати на увазі, що висновки судово-медичних експертиз містять лише медичну оцінку наслідків злочинного діяння і саме в такому розумінні вони повинні оцінюватися судами при вирішенні питання про доведеність винува- 
тості особи у злочині, обставин його вчинення та про його кримінально-правову кваліфікацію...» [6].

Так, наприклад Верхньодніпровський районний суд Дніпропетровської області встановив, що обвинувачений, маючи намір спрямований на заподіяння потерпілому тілесних ушкоджень, усвідомлюючи свої протиправні дї та бажаючи їх подальшого настання, умисно, цілеспрямовано, кулаками своїх обох рук наніс потерпілому не менше шести ударів в область голови від яких останній впав на землю. В цей час винний підійшов до лежачого на землі потерпілого, підняв його з землі та маючи намір спрямований на заподіяння останньому тілесних ушкоджень, усвідомлюючи свої протиправні дії та бажаючи їх подальшого настання, умисно, цілеспрямовано кулаком своєї правої руки наніс один удар в область обличчя, від якого останній впав на стоячий біля входу в жилий будинок тапчан після чого, продовжуючи переслідувати свій злочинний намір наніс ще не менше шести ударів потерпілому в область тулуба. Від отриманих тілесних ушкоджень настала смерть потерпілого. Згідно висновку судово-медичної експертизи, потерпілому було заподіяно тілесні ушкодження у вигляді закритої тупої черепно-мозкової травми з крововиливами під м'якими мозковими оболонками та внутрішньо мозковими крововиливами в ділянках обох тім'яних долей головного мозку, синцями на шкірі верхніх та нижніх повік обох очей, на перехідній обвідці нижньої губи травма $\epsilon$ прижиттєвою, могла утворитися від дії тупого твердого предмету (предметів) з обмеженою контактуючою поверхнею, або при співударі о такий (такі), знаходиться в прямому причинному зв'язку з причиною смерті та відноситься до тяжких тілесних ушкоджень за критерієм небезпеки для життя стосовно до живих осіб. Виявлені при проведенні судово-медичної експертизи трупа тілесні ушкодження могли бути утворені від дії тупого твердого предмету (предметів) з обмеженою контактуючою поверхнею, або при співударі о такий (такі), не виключено, зокрема, від ударів долонями, або (а також) кулаками рук, або (а також) ногами, взутими у взуття [13].

Таким чином, ми можемо побачити наявність умислу винних осіб на спричинення саме тілесних ушкоджень, які діяли з прямим умислом, тобто усвідомлювали суспільно небезпечний характер своїх дій, передбачали настання суспільно небезпечних наслідків у вигляді 
спричинених тілесних ушкоджень і бажали їх настання. Однак, щодо настання смерті, то ставлення винної особи може бути як у вигляді злочинної самовпевненості, тобто особа передбачала настання наслідків у вигляді смерті, однак розраховувала на те, що смерть не настане. У разі, коли особа не передбачала можливість настання смерті, то необхідна кваліфікація за ст. 119 КК України.

Слід звернути увагу на умисну форму вини у вигляді непрямого умислу, коли винна особа, хоча і передбачала настання суспільно небезпечних наслідків у вигляді смерті і хоча не бажала, але свідомо припускала, що смерть від ії дій може настати, то кваліфікація за ч. 2 ст. 121 КК України у такому випадку виключається і потребує кваліфікації за ст. 115 КК України.

Таким чином, можемо зазначити, що основною відмінністю умисного вбивства від заподіяння тяжких тілесних ушкоджень, внаслідок яких настала смерть потерпілого, - за суб'єктивною стороною, а саме ставлення винного до діяння та двох видів наслідків (тілесних ушкоджень і смерті). Суб’єкт злочину - загальний: фізична, осудна особа. Вік знижений - за заподіяння умисних тяжких тілесних ушкоджень кримінальній відповідальності підлягають особи, яким до вчинення злочину виповнилося 14 років.

\section{5. Аналіз судової практики}

Результати аналізу об'єктивних та суб'єктивних ознак 25 обвинувальних вироків судів України за ч. 2 ст. 121 КК України за 2018-2020 роки, є наступними:

1. 325 вироків попередня кваліфікація яких за ч. 2 ст. 121 КК України залишилась в 19 випадках, в одному випадку винна особа засуджена за ч. 1 ст. 119 КК України за вчинення вбивства 3 необережності. Об'єктивні ознаки вказали на штовхання потерпілого, від чого останній впав на підлогу, отримав травму голови, яка стала причиною смерті. Винний не передбачав можливості настання смерті потерпілого, хоча міг і повинен був передбачити такі наслідки. Один злочин, попередня кваліфікація за ч. 2 ст. 121 КК України, було виправдано в суді. Однак, в суді було з'ясовано, що обвинувачений знаходився в стані необхідної оборони і для захисту свого життя від реального групового озброєного нападу (ч. 5 ст. 36 КК України) вчинив умисне вбивство. 
2. Знаряддя: 325 злочинів, в 11 випадках, винними були застосовані предмети, якими спричинені тілесні ушкодження, до яких можна віднести: дерев'яну палицю, дерев'яну дошку, металеву сковорідку, металеву фомку, металеву монтировку, дерев'яну штахету, металевий штир, фрагмент металевої труби, дерев'яну тростину, дерев'яний табурет. Застосування різноманітних, підручних предметів говорить про спонтанність прийняття рішення щодо побиття та нанесення тілесних ушкоджень. Всі перелічені предмети мають господарсько-побутове призначення і не мають властивостей спеціального пристосування для нанесення тілесних ушкоджень. Такі розповсюджені знаряддя злочину для нанесення тілесних ушкоджень, як кухонні ножі не часто використовуються. Інші 11 тілесних ушкоджень були спричинені руками (рука зжата в кулак) та ногами (взутими у взуття). У випадках із застосуванням знарядь, побиття розпочиналось також руками та ногами i вже в ході побиття були додані підручні знаряддя, які знаходились на місці злочину. У випадку із дошкою потерпілому було нанесено удар по голові, пізніше винний поклав дошку на потерпілого і почав на ній стрибати, а інший в цей час наніс удар ногою в голову. Така поведінка винних, говорить про спонтанність прийняття рішення, нерівновагу, нестриманість, а також прояви спонтанної люті та агресії.

3. Обтяжуючи обставини: 325 вироків, було притягнуто до відповідальності 22 особи; 21 злочин було вчинено в стані алкогольного сп'яніння, з них у 19 випадках, вчиненому злочину, передувало спільне розпиття спиртних напоїв разом з потерпілими. Окрім того, у п’яти випадках, потерпілими були особи похилого віку, у десяти випадках винний і потерпілий перебували у родинному зв'язку - співмешканці, син - батько, онук - баба; чотири випадки, пов'язані із рецидивом злочину.

4. Характер, кількість та локалізація спричинених тілесних ушкоджень: $з 25$ проаналізованих вироків, у 24 випадках винним було нанесено декілька ударів 3-8 ударів, чисельні удари 9-20. В середньому удари наносились не менше 10 раз в різні частини тіла. Більшість злочинів мали розрив у часі між спричиненими тілесними ушкодженнями та настанням смерті. Розрив у часі за висновками судово-медичних експертів складав декілька годин. Локалізація ударів: по обличчю, голові, тулубу (грудна клітина, кінцівки рук та ніг). Характер тілесних 
ушкоджень, за висновками судово-медичних експертиз, наступний: чисельні синці, перелами ребер, носу, рук, ніг. Смерть у більшості випадків наставала від черепно-мозкових травм 3 крововиливом під оболонку головного мозку, або від гострої внутрішньої кровотечі. Отже, 3'ясування характеру та локалізації тілесних ушкоджень 3 метою встановлення злочинних намірів вказує на те, що у всіх випадках удари наносились неодноразово і в життєво важливі органи: голова, тулуб. Характер спричинених тілесних ушкоджень та наслідки у вигляді смерті говорять про наявну значну силу, яка прикладалася для досягнення конкретної мети. Слід також звернути увагу на випадки, коли ми говоримо про існування подвійної вини щодо прямого умислу на спричинення тяжких тілесних ушкоджень та необережності щодо смерті особи. У таких випадках постає питання: Чи може бути удар, наприклад, металевою монтировкою по голові потерпілого вчинений 3 необережності?

5. Співучасть: із 25 випадків, у 23 - злочин вчинено одноособово. У двох випадках злочин вчинено двома співучасниками, без попередньої змови під час обоюдної бійки. Тут ми можемо побачити характерну для таких видів злочинів просту форму співучасті, коли кожен із співучасників виконує свою частину об'єктивної сторони злочину, а саме нанесення ударів потерпілій особі, при цьому кожен 3 них усвідомлює злочинний характер вчинюваних ними дій, тому обидва співучасника підлягають кримінальній відповідальності.

6. Наявність попередньої судимості: у 13 випадках особи раніше не судимі, чи судимість знята або погашена на підставі ст. 89 КК України. Три особи, які раніше мали судимість за ч. 2 ст. 121, ч. 1 ст. 121, ст. 125 КК України, 3 них одна винна особа - жінка. Три мали попередні судимості за статтями 185, 186, 187 КК України. Інші судимості не мали, або судимість погашена на підставі ст. 89 КК України.

7. Психічне ставлення до наслідків: у 9 випадках винні особи не визнали свою вину у вчиненні злочину, з них два вказали на самозахист. У семи випадках вину визнали частково, не зізнавшись у кількості спричинених тілесних ушкоджень. Всі винні особи зазначили на відсутність умислу щодо настання смерті потерпілих. Мотив у всіх 25 випадках зазначений як «особисті неприязні стосунки». Відносно співмешканців, мотивом $є$ ревнощі. 


\section{6. Висновки}

Офіційні статистичні дані, за період з 2015 по 2019 роки, надають нам змогу зазначити, що на фоні загального зниження рівня злочинності у 2017-2018 роках, показники за ч. 2 ст. 121 КК України залишились майже незмінними і становлять 1,3\% - 1, 7\% від загальної кількості злочинів проти життя та здоров'я особи. Від загальної кількості вбивств, ч. 2 ст. 121 КК України складає від 8\% до 11, 3\%, при чому найбільші показники зафіксовані у 2017 та 2018 роках. Від загальної кількості тяжких тілесних ушкоджень, такі, що спричинили смерть потерпілому становлять у межах від 27,1\% до $31 \%$. Більшість вчинених злочинів за ч. 2 ст. 121 КК України вчиняються на побутовому грунті, в результаті раптово виниклих неприязних стосунків, що вказує на наявну проблему.

Проведений аналіз судової практики щодо розмежування умисного вбивства та тяжких тілесних ушкоджень, що спричинили смерть особи вказує на те, що відмежування відбувається за суб'єктивною стороною, а саме за ставленням винного до смерті потерпілої особи. Однак, встановити наміри можливо лише при детальному вивченні обставин об'єктивної сторони злочину. Тяжке тілесне ушкодження, як і умисне вбивство, за моментом закінчення $є$ злочинами з матеріальним складом, які передбачають наявність трьох основних складових: суспільно небезпечного діяння, суспільно небезпечних наслідків і причинного зв'язку між ними. Оскільки основні складові частини є однаковими як для вбивства, так і для тяжких тілесних ушкоджень, що спричинили смерть потерпілої особи, то для остаточного відмежування від вбивства встановлення лише обов'язкових компонентів недостатньо. Тому, виникає необхідність встановлювати додаткові (факультативні) ознаки об'єктивної сторони, які не можуть обмежуватися загально прийнятими, як-от: час, місце, спосіб, обстановка, знаряддя та засоби вчинення злочину. Для більш точної кваліфікації необхідно встановити й додаткові обставини, а саме: характер та локалізацію тілесних ушкоджень, кількість нанесених тілесних ушкоджень, наявність попередніх стосунків між винним та потерпілим, поведінку винного після спричинення тілесних ушкоджень, ставлення винного до настання смерті потерпілого та інші, враховуючи обставини конкретного випадку. 3'ясування розширеного кола поставлених задач надає змогу встановити розмежування між 
вбивством та тяжким тілесним ушкодженням, що спричинило смерть потерпілої особи. Також, особливу увагу необхідно приділити знаряддю вчинення злочину. Так, розглянувши обвинувальні вироки судів України можна дійти висновку, що у всіх випадках, умисел на спричинення тілесних ушкоджень виник миттєво, не сплановано на грунті раптово виниклих неприязних стосунків, в результаті чого тілесні ушкодження, у більшості випадків, були спричинені руками (рукою зжатою в кулак) та ногами. Рідше тілесні ушкодження спричиняються різними предметами, які мають побутове призначення, що знову ж таки вказує на спонтанність, не спланованість спричинення смерті потерпілому. Як ми можемо побачити, детальний розгляд і встановлення факультативних ознак об’єктивної сторони злочину дають можливість правильної кваліфікації та розмежування вбивства та тяжких тілесних ушкоджень, що спричинили смерть потерпілої особи.

\section{Список літератури:}

1. Офіційні статистичні данні за 2015 рік. Єдиний звіт про кримінальні правопорушення по державі за 2015 рік. URL: https://old.gp.gov.ua/ua/stst2011. html?dir id=112173\&libid=100820 (дата звернення: 10.04.2020).

2. Офіційні статистичні данні за 2016 рік. Єдиний звіт про кримінальні правопорушення по державі за 2016 рік. URL: https://old.gp.gov.ua/ua/stst2011. html?dir_id=112661\&libid=100820 (дата звернення: 10.04.2020).

3. Офіційні статистичні данні за 2017 рік. Єдиний звіт про кримінальні правопорушення по державі за 2017 рік. URL: https://old.gp.gov.ua/ua/stst2011. html?dir id=113281\&libid=100820 (дата звернення: 10.04.2020).

4. Офіційні статистичні данні за 2018 рік. Єдиний звіт про кримінальні правопорушення по державі за 2018 рік. URL: https://old.gp.gov.ua/ua/stst2011. html?dir_id=113653\&libid=100820 (дата звернення: 10.04.2020).

5. Оффіційні статистичні данні за 2019 рік. Єдиний звіт про кримінальні правопорушення по державі за 2019 рік. URL: https://old.gp.gov.ua/ua/stst2011. html?dir_id=113897\&libid=100820 (дата звернення: 10.04.2020).

6. Про судову практику в справах про злочини проти життя та здоров'я особи : Постанова Пленуму Верховного суду України від 07.02.2003 № 2 . URL: https://zakon.rada.gov.ua/laws/show/v0002700-03 (дата звернення: 01.04.2020).

7. Вирок Кіровського районного суду м. Кіровограда. Справа № 404/2559/19. Номер провадження 1-кп/404/177/19. URL: http://reyestr.court.gov.ua/ Review/85848626 (дата звернення: 02.04.2020).

8. Постанова колегії суддів Першої судової палати Касаційного кримінального суду Верховного Суду 25 квітня 2019 року. Справа №163/353/17. Провадження № 51-7582 км 18. URL: https://zakononline.com.ua/court-decisions/show/81426040 (дата звернення: 03.04.2020). 
9. Вирок Олександрівського міськрайонного суду Кіровоградської області. Справа № 398/2917/19. Номер провадження 1-кп/398/162/20. URL: http://reyestr.court.gov.ua/Review/88737051 (дата звернення: 16.04.2020).

10. Вирок Комінтернівського районного суду м. Харкова. Справа № 641/1823/20. Номер провадження 1-кп/641/476/2020. URL: http://reyestr.court.gov.ua/Review/88714275 (дата звернення: 18.04.2020).

11. Вирок Самбірського міськрайонного суду Львівської області. Справа № 455/1364/19. Номер провадження 1-кп/452/22/2020. URL: http://reyestr.court.gov.ua/Review/88586980 (дата звернення: 19.04.2020).

12. Вирок Шепетівського міськрайонного суду Хмельницької області. Справа № 688/4002/1. Номер провадження 1-кп/688/273/19. URL: http://reyestr.court.gov.ua/Review/86683167 (дата звернення: 12.04.2020).

13. Вирок Верхньодніпровського районного суду Дніпропетровської області. Справа № 455/1364/19. Номер провадження 1-кп/452/22/2020. URL: http://reyestr.court.gov.ua/Review/88541517 (дата звернення: 20.04.2020).

\section{References:}

1. Oficijni statystychni danni za 2015 rik. Jedynyj zvit pro kryminaljni pravoporushennja po derzhavi za 2015 rik [Official statistics for 2015. The only report on criminal offenses in the state for 2015]. Retrieved from: https:/old.gp.gov.ua/ua/ stst2011.html?dir_id=112173\&libid=100820 (accessed 10.04.2020).

2. Oficijni statystychni danni za 2016 rik. Jedynyj zvit pro kryminaljni pravoporushennja po derzhavi za 2016 rik [Official statistics for 2016. The only report on criminal offenses in the state for 2016]. Retrieved from: https://old.gp.gov.ua/ua/ stst2011.html?dir id=112661\&libid=100820 (accessed 10.04.2020).

3. Oficijni statystychni danni za 2017 rik. Jedynyj zvit pro kryminaljni pravoporushennja po derzhavi za 2017 rik [Official statistics for 2017. The only report on criminal offenses in the state for 2017]. Retrieved from: https:/old.gp.gov.ua/ua/ stst2011.html?dir id=113281\&libid=100820 (accessed 10.04.2020).

4. Oficijni statystychni danni za 2018 rik. Jedynyj zvit pro kryminaljni pravoporushennja po derzhavi za 2018 rik [Official statistics for 2018. The only report on criminal offenses in the state for 2018]. Retrieved from: https:/old.gp.gov.ua/ua/ stst2011.html?dir_id $=113653 \&$ libid $=100820$ (accessed 10.04.2020).

5. Oficijni statystychni danni za 2019 rik. Jedynyj zvit pro kryminaljni pravoporushennja po derzhavi za 2019 rik [Official statistics for 2019. The only report on criminal offenses in the state for 2019]. Retrieved from: https:/old.gp.gov.ua/ua/ stst2011.html?dir_id=113897\&libid=100820 (accessed 10.04.2020).

6. Pro sudovu praktyku v spravakh pro zlochyny proty zhyttja ta zdorov'ja osoby : Postanova Plenumu Verkhovnogho sudu Ukrajiny vid 07.02.2003 № 2 [Legal Practice in Crimes against Life and Health : Resolution of the Plenum of the Supreme Court of Ukraine of February 07, 2003 No. 2]. Retrieved from: https://zakon.rada.gov.ua/laws/show/v0002700-03 (accessed 01.04.2020).

7. Vyrok Kirovsjkogho rajonnogho sudu m. Kirovoghrada. Sprava № 404/2559/19. Nomer provadzhennја 1-кп/404/177/19 [Verdict of the Kirov 


\section{Svetlana Shalgunova, Alexandra Skok}

District Court of Kirovograd. Case No. 404/2559/19. Production number 1-kp / 404/177/19]. URL: http://reyestr.court.gov.ua/Review/85848626 (accessed 02.04.2020).

8. Postanova koleghiji suddiv Pershoji sudovoji palaty Kasacijnogho kryminaljnogho sudu Verkhovnogho Sudu 25 kvitnja 2019 roku. Sprava № 163/353/17. Provadzhennja № 51-7582 km 18 [Resolution of the College of Judges of the First Judicial Chamber of the Supreme Court of Cassation of Criminal Justice on 25 April 2019. Case \# 163/353/17. Proceedings No. 51-7582 km 18]. URL: https://zakononline.com.ua/court-decisions/show/81426040 (accessed 03.04.2020).

9. Vyrok Oleksandrivsjkogho misjkrajonnogho sudu Kirovoghradsjkoji oblasti. Sprava № 398/2917/19. Nomer provadzhennja 1-kp/398/162/20 [The verdict of the Alexander City Court of the Kirovograd region. Case No. 398/2917/19. Production number 1-kp / 398/162/20]. URL: http://reyestr.court.gov.ua/Review/88737051 (accessed 16.04.2020).

10. Vyrok Kominternivsjkogho rajonnogho sudu m. Kharkova. Sprava № 641/1823/20. Nomer provadzhennja 1-kp/641/476/2020 [Verdict of the Kominternovsky District Court of Kharkiv. Case No. 641/1823/20. Procedure number 1-kp / 641/476/2020]. URL: http://reyestr.court.gov.ua/Review/88714275 (accessed 18.04.2020).

11. Vyrok Sambirsjkogho misjkrajonnogho sudu Ljvivsjkoji oblasti. Sprava № 455/1364/19. Nomer provadzhennja 1-kp/452/22/2020 [Sambir City Court verdict in Lviv region. Case No. 455/1364/19. Procedure number 1-kp / 452/22/2020]. URL: http://reyestr.court.gov.ua/Review/88586980 (accessed 19.04.2020).

12. Vyrok Shepetivsjkogho misjkrajonnogho sudu Khmeljnycjkoji oblasti. Sprava № 688/4002/1. Nomer provadzhennja 1-kp/688/273/19 [The verdict of Shepetivsky City Court of Khmelnytsky region. Case No. 688/4002/1. Procedure number 1-kp / 688/273/19]. URL: http://reyestr.court.gov.ua/Review/86683167 (accessed 12.04.2020).

13. Vyrok Verkhnjodniprovsjkogho rajonnogho sudu Dnipropetrovsjkoji oblasti. Sprava \# 455/1364/19. Nomer provadzhennja 1-kp/452/22/2020 [Verdict of Verkhnodniprovsky District Court of Dnipropetrovsk Oblast. Case No. 455/1364/19. Procedure number 1-kp / 452/22/2020]. URL: http://reyestr.court.gov.ua/ Review/88541517 (accessed 20.04.2020). 